\title{
Reducing Waste using Integration of Lean Six Sigma and TRIZ Method: A Case Study in Wood Manufacturing Industry
}

\author{
Dian Hadi Purnomo ${ }^{a *}$, Muhammad Lukman ${ }^{b}$ \\ a Department of Industrial Management National Formosa University, Taiwan \\ Address: No. 64, Wenhua Road, Huwei Township, Yunlin County, Taiwan \\ b Department of Industrial Engineering, Universitas Muhammadiyah Malang, Indonesia \\ Jl.Raya Tlogomas No. 246, Tlogomas, Kota Malang, Jawa Timur 65144, Indonesia \\ * Corresponding author: dianhp.education@gmail.com
}

\section{ARTICLE INFO}

Article history

Received May 27, 2020

Revised August 10, 2020

Accepted August 18, 2020

Available Online August 30, 2020

Keywords

Waste

Lean

Lean six-sigma

Lean manufacturing

TRIZ

\begin{abstract}
Recently, lean production has become a major focus of researchers and industry. The zero-waste concept holds an important role in the production process. The aim of this concept is to reduce waste and increase productivity. Wastes have significant negative impacts on the company, one of which is the decrease of company profit. This research aimed to integrate the Lean Six Sigma method with Teorya Resheniya Izobreatatelskikh Zadatch (TRIZ) in order to reduce wastes. These two methods were applied with Define-Measure-Analyze-Improve-Control(DMAIC) methodology. A case study was conducted in a wood manufacturing company. The results of the study suggest that the application of the two methods can significantly reduce the Non-value Added (NVA).
\end{abstract}

This is an open-access article under the CC-BY-SA license.

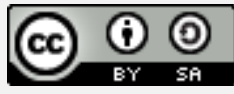

\section{Introduction}

Researchers and industrial persons have recently made lean production their chief focus [1]. The zero-waste concept plays an important role in manufacturing and production [2] [3]. The concept targets the reduction of waste and the increase of company productivity [4]. Waste problems that many companies face in their production lines include waiting, defect, over-production, and inventory [5]. Waste problems cause a significant loss for the company, including profit loss. Therefore, the key to increase profit is by boosting efficiency in the production lines [6].

The implementation of lean manufacturing is crucial in the waste reduction procedure [7] [8] [9]. The efficiency of lean manufacturing has convinced researchers to adapt the lean concept into the industry, such as what has been found by Rahman, et al. [10], Amrina and Lubis [8], Romero, et al. [11], Bai, et al. [12], and Ade and Deshpande [13]. Lean manufacture comprises of series of methods used to minimize machine downtime, inventory, re-work, and waste [14]. Furthermore, the six sigma method is also proven to be effective for the company's systematic improvement, which can improve customer satisfaction and profit [15]. The integration of the two tools (Lean and Six Sigma), which can be called the Lean Six Sigma (LSS), helps the company to reach an

d.

https://doi.org/10.22219/JTIUMM.Vol21.No2.139-152 Www http://ejournal.umm.ac.id/index.php/industri ti.jurnal@umm.ac.id

Please cite this article as: Purnomo, D. H., \& Lukman, M. (2020). Reduce Waste using Integration of Lean Six Sigma and TRIZ Method: A Case Study in Wood Industry. Jurnal Teknik Industri, 21(2), 139-152. https://doi.org/10.22219/JTIUMM.Vol21.No2.139-152 
optimum result, which might not be achieved when either one is implemented [16] [17] [18]. Reflecting on the research by Thomas, et al. [19], this research implemented the LSS method to minimize the variations and the critical to quality (CTQ) during the production process. Micu [20], Manfredsson, et al. [21], Belekoukias, et al. [22], Chiarini [23], and Chiarini and Bracci [24] applied the Define-Measure-Analyze-Improve-Control (DMAIC) methodology.

Research on the implementation of Lean Six Sigma (LSS) and Teorya Resheniya Izobreatatelskikh Zadatch (TRIZ) approach has been found in the food industry, such as the research by Soti, et al. [25], Costa, et al. [26], and Nabhani, et al. [27]. There has been no research on the implementation of LSS and TRIZ in the wood manufacturing industry. This research proposed using LSS and TRIZ as an alternative approach to minimize wastes in the wood manufacturing industry. TRIZ is a method designed by Grenrich Altshuller in 1940 to solve contradictory problems in production [28]. The objective of this research is to integrate LSS and TRIZ to reduce waste in the process of production in the wood manufacturing industry.

This article discusses the proposal and data collection methods in the second section, the results and discussion in the third section, and the conclusion in the end.

\section{Methods}

The research proposed integrating two methods, namely LSS and TRIZ, in the production lines in the wood manufacturing industry. LSS is a tool that is proven to be able to reduce waste effectively [29]. TRIZ is a method that can help solve contradictory problems [28]. These two methods were applied in the research with DMAIC methodology. The stages of the proposed solution method are presented in Fig. 1.

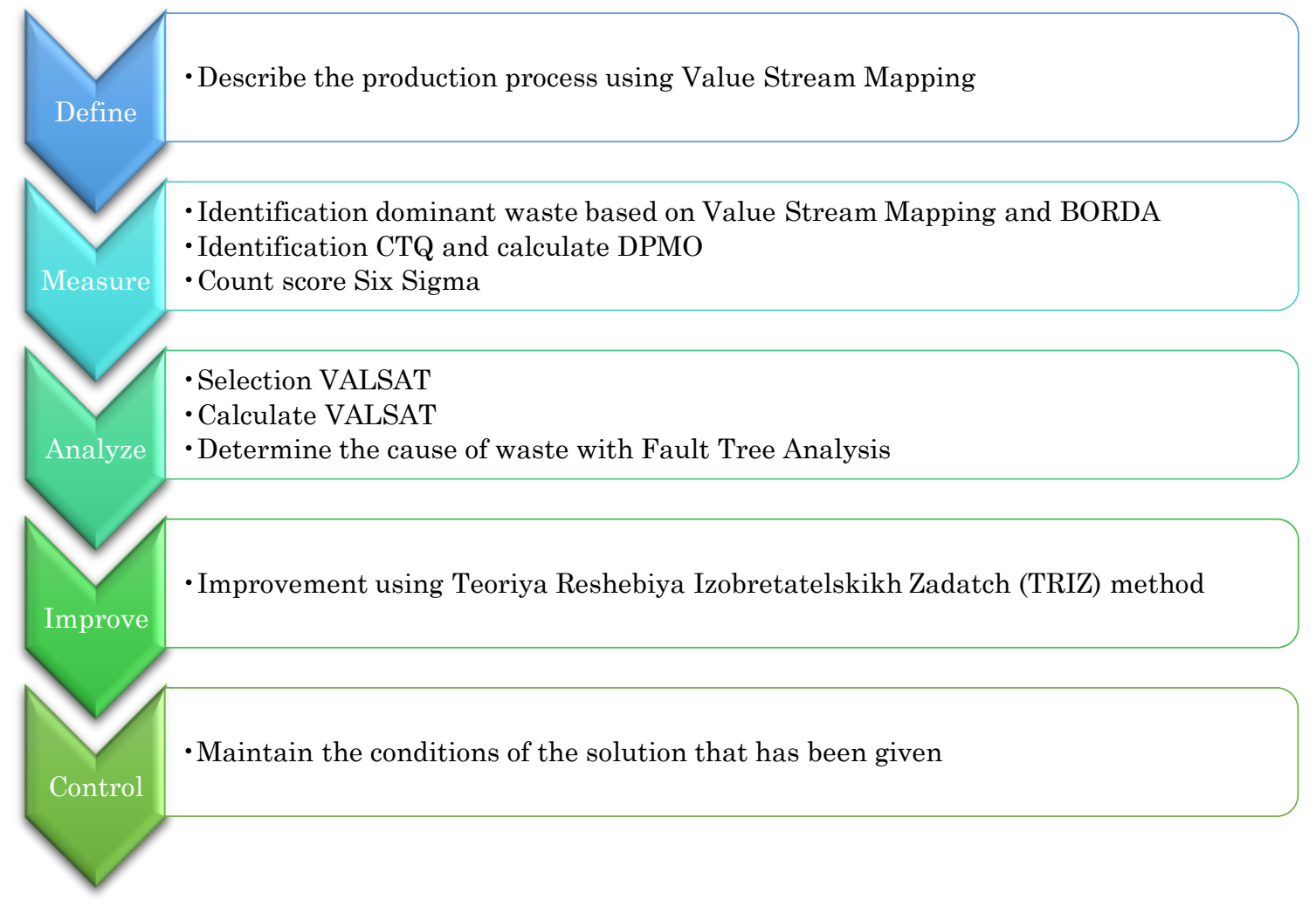

Fig. 1. The stages of Procedure Integration of Lean Six Sigma and TRIZ 


\subsection{Define Procedure}

At the "define" stage, the activities involved during the production process are identified. The researcher implemented the Value Stream Mapping (VSM) method to illustrate the results of the identification. The data needed for the VSM method are including machine (MC), manpower (MP), cycle time (CT), and available time (AT). Implementing the VSM method resulted in the identification of the overall production process time throughout the value stream.

\subsection{Measure Procedure}

The "measure" stage concerns the follow-up of the "define" stage. At this stage, the performance of the process is assessed. The process performance can be used to measure the general performance in order to achieve the expected production. In this research, the lean function was used to identify waste using the BORDA questionnaire [30]. For the data sampling, the purposive sampling method was used. At the subsequent stage, dominant waste identification was conducted using CTQ. A Pareto diagram was used to select the characteristics of the CTQ [31]. Next, the calculation of the sigma value employed the Defect Per-Million Opportunities (DPMO) method [32].

\subsection{Analyze Procedure}

The analysis on the causal relation of the waste is conducted at the "analysis" stage. The research employed Value Stream Analysis Tools (VALSAT) to calculate and determine the appropriate tools based on measurement [33]. Identifying the waste causes was presented in a Fault Tree Analysis (FTA) [34].

The selection of VALSAT was conducted by multiplying the measurement results with the VALSAT matrix. The multiplication results revealed the information about the identification of the waste, including the waste rankings. After the appropriate VALSAT analysis was determined, the selected VALSAT analysis was used to determine the total activities conducted based on the mapping tools.

The identification of the causes of waste was conducted using the FTA method. At this stage, the FTA functioned as the illustration that defined the problems and the conditions which caused the waste. From the FTA analysis, quantitative and qualitative analyses were conducted.

\subsection{Purposed Improve}

At the "improve" stage, the TRIZ method was used to present solutions obtained from the previous analyses. The steps required to conclude the solutions using the TRIZ method are as follows: a. Identifying and understanding the problems happening during the production process; b. and determining and formulating the problems which are illustrated in the form of contradictions; c. Solving the problems by providing solutions to the contradictions [35].

\subsection{Control Procedure}

The final stage of the DMAIC methodology is the "control" stage. This research employed the Standard Operational Procedures (SOP) from the selected company to conduct control based on the provided solutions. 


\subsection{Data Collection Procedure}

A case study was conducted in a wood manufacturing company in Indonesia. The data on a machine (MC), manpower (MP), cycle time (CT), available time (AT), and CTQ of each waste was collected for VSM illustration. Furthermore, the data collection was conducted at the measurement stage by distributing a questionnaire to 30 respondents. The questionnaire attributes included seven wastes that were identified in the company. The wastes were over-production, waiting, excessive transportation, unnecessary inventory, unnecessary motion, and defect measured with a scale of 1 to 5 .

\section{Results and Discussion}

\subsection{Result of Define}

The result obtained at this stage was the VSM illustration which was identified from the production process. Fig. 2 illustrates the results of mapping using VSM. The results show that the total Value Added (VA) was 1.974 seconds, and the Value Stream (VS) was 13.074 seconds. On the other hand, the Non-Value Added (NVA) and the Necessary Non-Value Added (NNVA) were 2.400 seconds. This result was obtained from the subtraction of VA with VS. The result shows that Non-Value Added (NVA) and NonNecessary Value Added (NNVA) had significantly high values. These values also show that actions need to be taken to minimize the Non-Value Added (NVA).

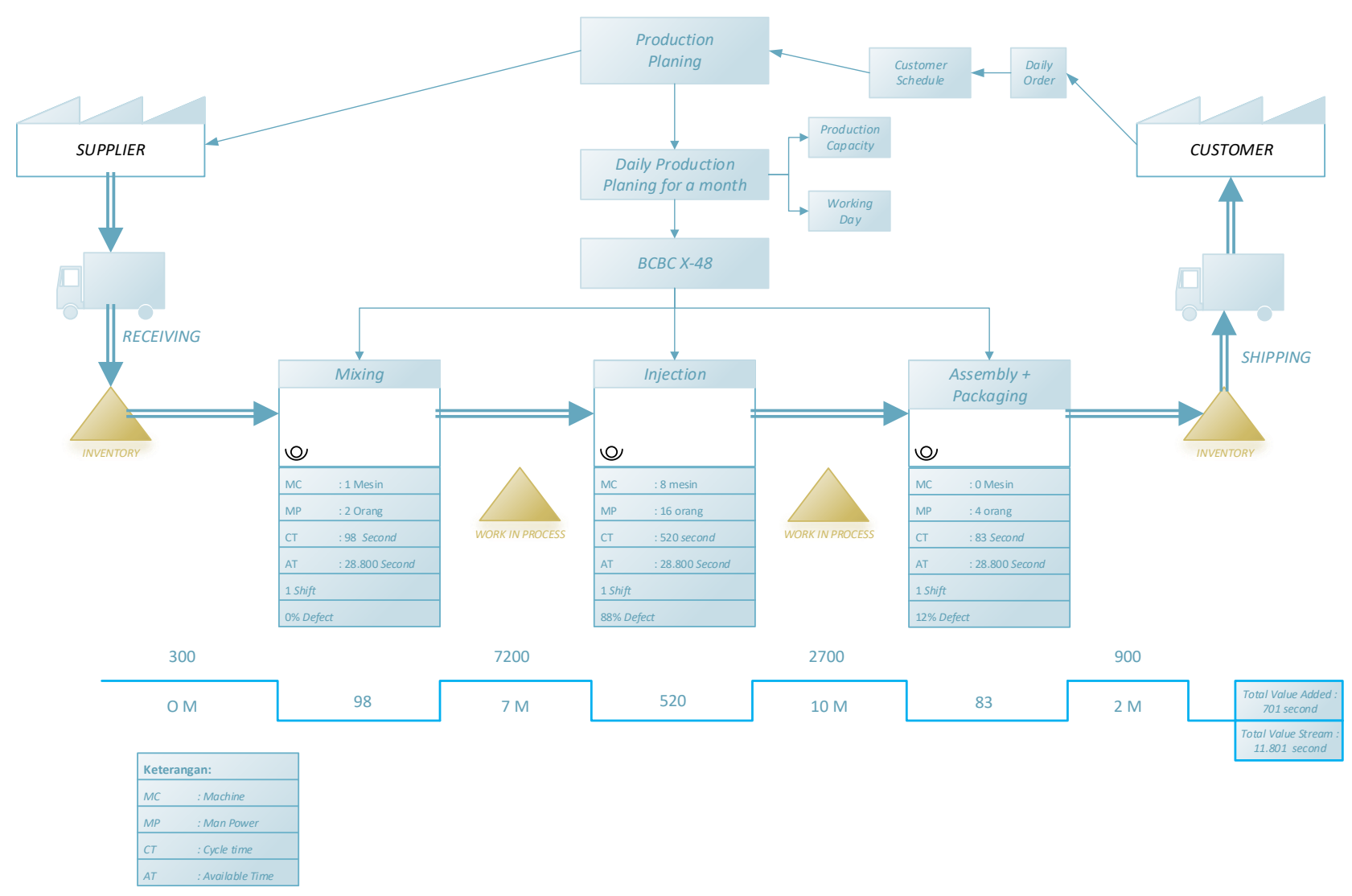

Fig. 2. The Mapping of Current Value Stream 


\subsection{Result of Measure}

At this stage, the waste identification was obtained from the BORDA questionnaire results. The CTQ factor was the approach used to analyze and evaluate waste. Referring to the research conducted by Tsarouhas [36] and Kothavale, et al. [37], the statistical method was used to conduct the analysis. Fig. 3 illustrates the Pareto diagram, which shows the waste during the production process in a wood factory. In this research, the Pareto principle of $80 / 20$ was employed. The Pareto diagram indicated that the most significant waste factor was the waiting factor with a percentage of $30 \%$. The second crucial waste factor was over-production which stood at $23.33 \%$. It was followed by defect and inventory, which accounted for $20 \%$ and $10 \%$ of the total waste identified. These findings are in line with the findings obtained by Alsaffar and Ketan [38]. They identified waiting as the most significant waste factor.

The next stage was to calculate the sigma value of the dominant components causing waste. The CTQ identification was conducted in order to determine the specific criteria which influenced the quality of a product. Table 1 shows defect as the main factor, with a CTQ value of 8 . Following this, both inventory and waiting scored a CTQ value of 2, while over-production scored a CTQ value of 1 .

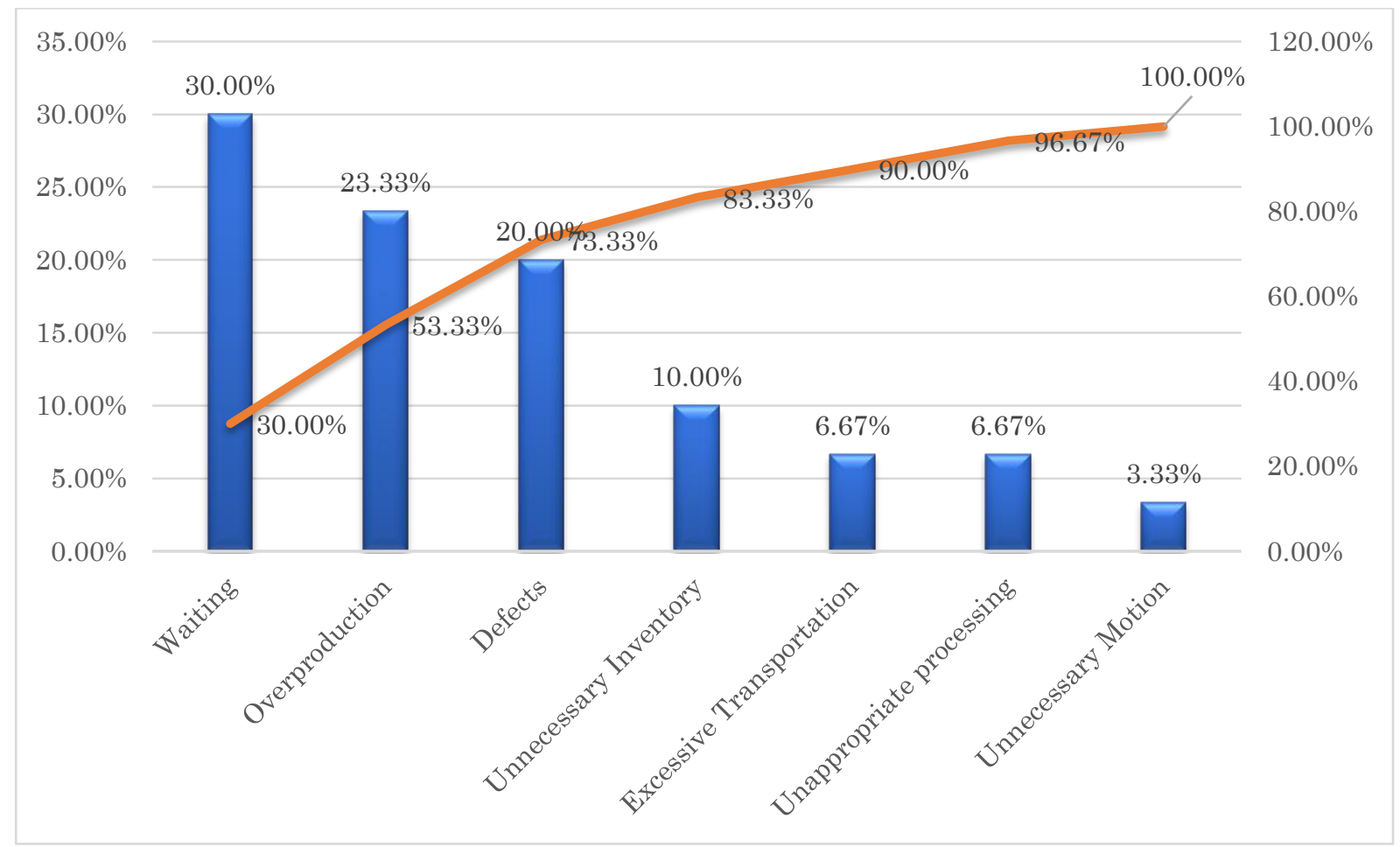

Fig. 3. The Pareto Diagram of Waste during Production Process

Table 2 shows the values of sigma based on the total CTQ in the dominant wastes. Waiting and overproduction scored sigma values of 1.784 and 1.850 , respectively, from the total of 2 CTQ for waiting and $1 \mathrm{CTQ}$ for overproduction. On the other hand, defect and inventory scored 3.796 and 3.834, respectively. Since the sigma values were below 6 , improvements were suggested. At the "improve" and "control" stages, the efforts to make improvements were conducted. 
Table 1. Critical to Quality (CTQ) of Product X

\begin{tabular}{|c|c|c|}
\hline Dominant Wastes & Critical to Quality & Total \\
\hline \multirow{8}{*}{ Defect } & Short Shot & \multirow{8}{*}{8} \\
\hline & Silver Streak & \\
\hline & Break & \\
\hline & Color Flow & \\
\hline & Wrinkle Waves & \\
\hline & Ejector Mark & \\
\hline & Water Spots & \\
\hline & Silicon Spots & \\
\hline \multirow{2}{*}{ Inventory } & $\begin{array}{l}\text { Inventory during waiting process for } \\
\text { Injection }\end{array}$ & \multirow[b]{2}{*}{2} \\
\hline & $\begin{array}{l}\text { Inventory during waiting process for } \\
\text { Assembly }\end{array}$ & \\
\hline \multirow{2}{*}{ Waiting } & $\begin{array}{l}\text { Waiting during Injection process due to } \\
\text { limited machinery }\end{array}$ & \multirow{2}{*}{2} \\
\hline & $\begin{array}{l}\text { Waiting during Assembly process due to } \\
\text { lack of assembly operators }\end{array}$ & \\
\hline Overproduction & $\begin{array}{l}\text { The total finished products exceeding the } \\
\text { production target }\end{array}$ & 1 \\
\hline
\end{tabular}

Table 2. The Recapitulations of Sigma Values of the Dominant Wastes

\begin{tabular}{lc}
\multicolumn{1}{c}{ Variety Waste } & Sigma Score \\
\hline Waste Waiting & 1.784 \\
\hline Waste Overproduction & 1.850 \\
\hline Waste Defect & 3.796 \\
\hline Waste Inventory & 3.834
\end{tabular}

\subsection{Result of Analyze}

The first stage of analysis is choosing the Value Stream Analysis (VSA) tools. In this research, the analysis stage was conducted using the table of Value Stream Analysis Tools (VALSAT) approach, designed by Hines and Rich [33]. Table 3 shows the data of the measurement recapitulation results obtained with the VALSAT approach. The measurement value was obtained from the percentage of questionnaire analysis. In Table 3 , three tools are scoring the highest waste measurement, namely Process Activity Mapping (PAM), Supply Chain Response Matrix (SCRM), and Quality Filter Mapping (QFM).

The VALSAT analysis results on PAM show that there were 13 waste activities during the production process; four operation activities, four transportation activities, two inspection activities, two delay activities, and one storage activity. Based on the total number of activities, the Value Added (VA) and Non-Value Added (NVA categories scored $5.95 \%$ and $73.72 \%$, respectively. Meanwhile, the Necessary Non-Value Added (NNVA) scored a $20.34 \%$. From these results, it can be concluded that NVA became a significant 
factor that caused a delay. Therefore, improvement during the "improve" and "control" stages must be performed to reduce the waste.

From the SCRM results, the longest day physical stock happened in the finished product area (2.8 days). This result indicates that the longest storage duration happened in the finished product area. Meanwhile, the longest lead time happened at the raw material area (7 days). This result is directly proportional to the production area's situation because raw materials piled up before moving to the mixing process.

From the QFM results, the main contributor for defect waste was the injection process which scored $88 \%$. The defect component during the injection process involved short shot, silver streak, break, color flow, wrinkle waves, ejector mark, water spots, and silicon spots.

Table 3. The Recapitulation of VALSAT Measurement

\begin{tabular}{rccccccc}
\hline & \multicolumn{1}{c}{ Mapping Tools } \\
\cline { 2 - 8 } Waste & $\begin{array}{c}\text { Process } \\
\text { Activity } \\
\text { Mapping }\end{array}$ & $\begin{array}{c}\text { Supply } \\
\text { chain } \\
\text { Response } \\
\text { Matrix }\end{array}$ & $\begin{array}{c}\text { Production } \\
\text { Variety } \\
\text { Funnel }\end{array}$ & $\begin{array}{c}\text { Quality } \\
\text { Filter } \\
\text { Mapping }\end{array}$ & $\begin{array}{c}\text { Demplification } \\
\text { Mapping }\end{array}$ & $\begin{array}{c}\text { Decision } \\
\text { Point } \\
\text { Analysis }\end{array}$ & $\begin{array}{c}\text { Physical } \\
\text { Structure }\end{array}$ \\
Total & 4.33 & 2.27 & 0.40 & 2.97 & 1.60 & 1.23 & 0.27 \\
\hline Rangking & 1 & 3 & 6 & 2 & 4 & 5 & 7 \\
\hline
\end{tabular}

At the cause identification stage, a Fault Tree Analysis was conducted to detect the causes of waste. The causes of waste were detected in each area. Fig. 4 shows the FTA results on PAM, which is a delay. Delay was caused by the waiting process before injection and assembly. During the injection process, two main factors were causing the delay; raw materials did not fulfill the required standard and the delay while removing the material from the molds. During the assembly process, the delay was caused by two factors; the machine layout was not balanced. The operators took a long time to assemble the components.

On the other hand, from the SCRM at the production area, three types of waste were found; inventory, over-production, and waiting, shown in Fig. 5. FTA can be the benchmark in finding the core problems of production process wastes. FTA can also illustrate in detail the causes of waste in the production process. By finding these problems and causes of waste, companies can improve efficiency during production.

\subsection{Result of Purposed Improve}

The NVA activity in some areas of the production process required some solutions. At this stage, reformation of working stations was performed in order to minimize the delay. However, if one parameter were to be fixed, other parameters would experience a decrease in performance. TRIZ method was chosen because this method could solve this problem [39]. The "improve" treatment for delayed waste is illustrated in Fig. 6. Furthermore, "improve" treatment on loss time in the production area is shown in Fig. 7. 


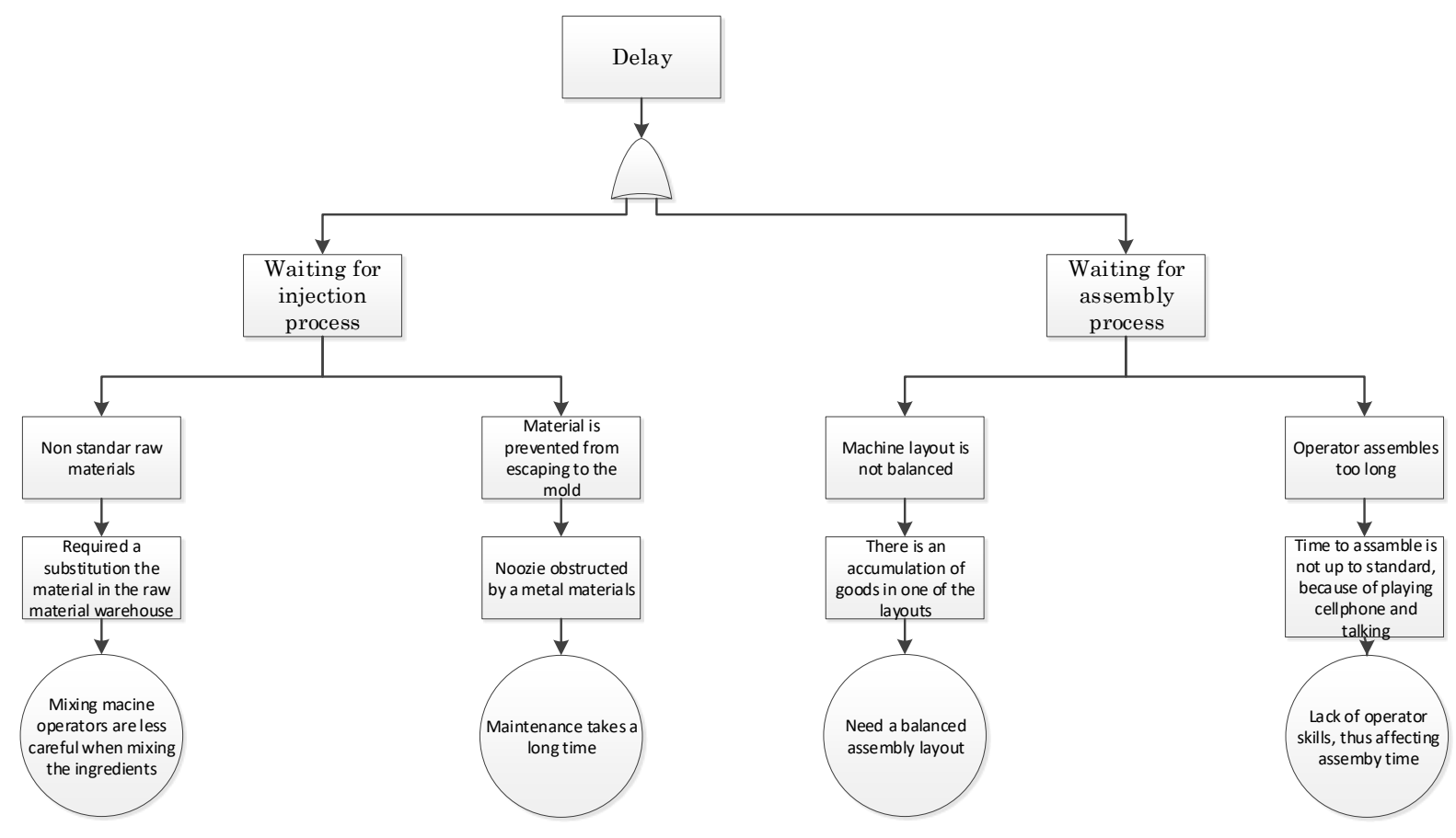

Fig. 4. Fault Tree Analysis on PAM

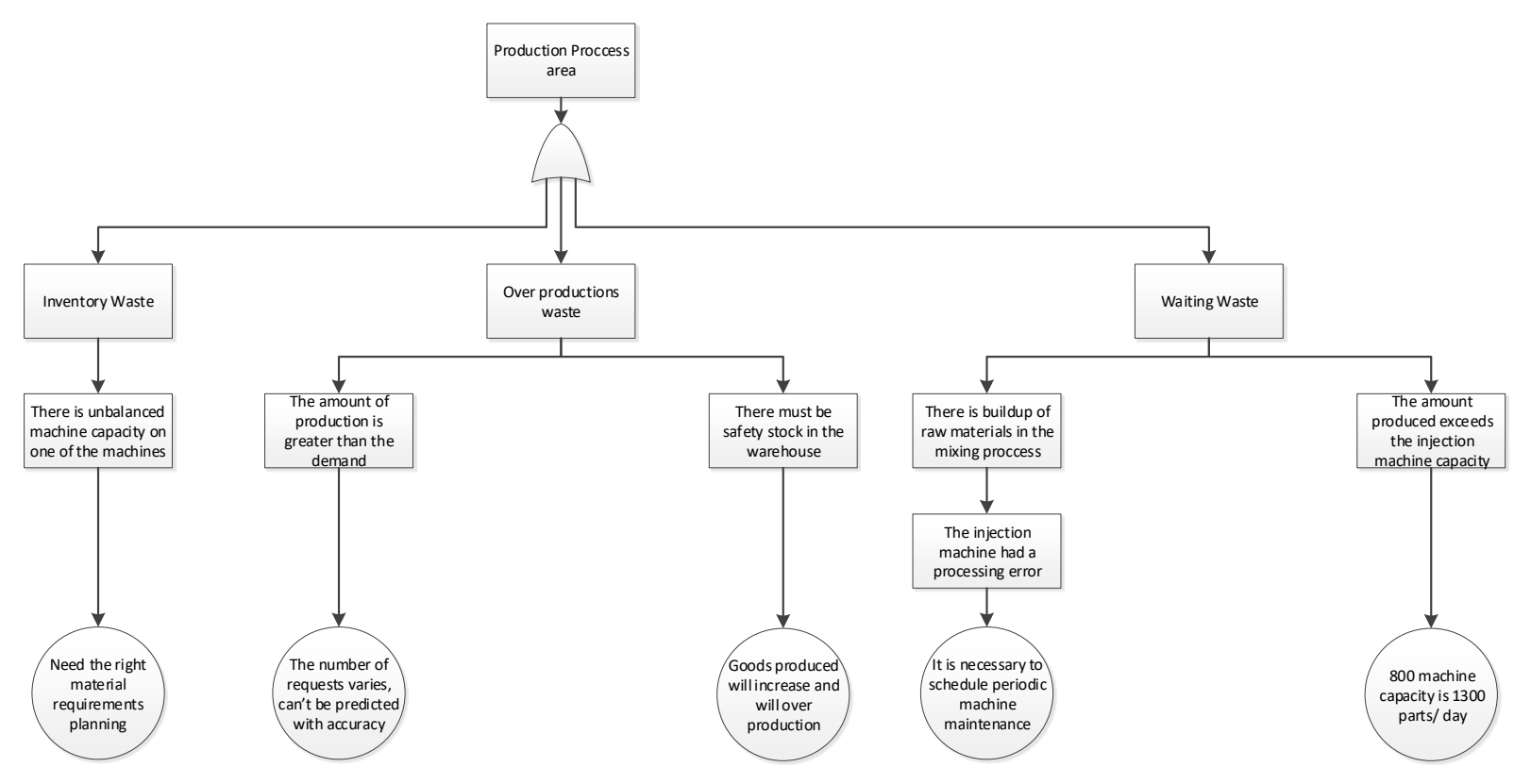

Fig. 5. Fault Tree Analysis on SCRM 


\begin{tabular}{|c|c|}
\hline Problems & Delay happening when assembling product $\mathrm{X}$ \\
\hline Contradictions & $\begin{array}{l}\text { The speed to assembly product } X><\text { The ease in assembling product } \\
X \\
\text { (9) Speed }><(32) \text { Ease of operation }[40]\end{array}$ \\
\hline $\begin{array}{l}\text { Contradiction } \\
\text { matrix }\end{array}$ & $32,28,13,12$ \\
\hline Solution & $\begin{array}{l}\text { Upon considering the condition in the factory and the problems } \\
\text { found by the Fault Tree Analysis, the proposed solution is as } \\
\text { follows. } \\
\text { C Principle } 12 \text { Equipotentially } \\
\text { Changing the operational condition of the product X assembly to } \\
\text { balanced working stations so that product X assembling process } \\
\text { time could be more effective and balanced [41]. }\end{array}$ \\
\hline
\end{tabular}

Fig. 6. The "improve" treatment for delayed waste

\begin{tabular}{|c|c|}
\hline Problems & $\begin{array}{l}\text { Lost of time while mixing the raw materials to become compound } \\
\text { affecting productivity. }\end{array}$ \\
\hline Contradictions & $\begin{array}{l}\text { Lost of time in mixing raw material } \mathrm{X}><\text { Productivity of product } \mathrm{X} \text {. } \\
\text { (25) Lost of Time }><\text { (39) Productivity }\end{array}$ \\
\hline $\begin{array}{l}\text { Contradiction } \\
\text { matrix }\end{array}$ & ALL \\
\hline Solutions & $\begin{array}{l}\text { Upon considering the condition in the factory and the problems } \\
\text { found by the Fault Tree Analysis, the proposed solutions are as } \\
\text { follows. } \\
\text { Instead of implementing continuous actions, periodic actions need to } \\
\text { be performed in order to change the frequency. After the arrival of } \\
\text { raw materials in the warehouse, the supplier requires around seven } \\
\text { days of lead time. When the raw materials are running out, the } \\
\text { mixing operators stop operating, which causes waiting time, } \\
\text { affecting the injection machine. Inventory check on the warehouse } \\
\text { needs to be performed regularly using the periodic action approach } \\
\text { [42]. }\end{array}$ \\
\hline
\end{tabular}

Fig. 7. The "improve" treatment for loss time in the production process

This research also employed Future Value Stream Mapping for the wood manufacturing industry. With Future Value Stream Mapping, the total Value Added (VA) was 940 seconds. Meanwhile, the activity of Non-Value Added (NVA) and Necessary NonValue Added (NNVA) respectively scored 0 seconds and 1.820 seconds, as shown in Fig. 8. Based on improvement using the TRIZ method, the decrease in the NVA activity was $100 \%$. 


\subsection{Result of Control}

The objective of the "control" stage is to ensure that improvements are continuous by reflecting on the Standard of Operational (SOP) [43]. In this research, two types of SOP were used as reference; SOP for compound-making raw materials mixing and SOP for molding injection.

The SOP for raw materials which are used to make compounds includes the following points; ensuring that the raw materials are by the composition standard, opening the mixer machine valve so that the raw materials can be poured in, pouring in the raw materials which have been measured into the mixer, closing the mixer valve tightly, setting the time based on the required duration, and making sure that the raw materials are well mixed and become a compound.

The SOP for molding injection involves the following points; turning in the machine at the distribution panel by pressing the switch button, switching on the NFB in each machine, switching on the heating machine until it reaches the standard temperature, setting the temperature following the standard, switching on the controlling tower to cool the machine, switching on the chiller. The machine is ready to be used.

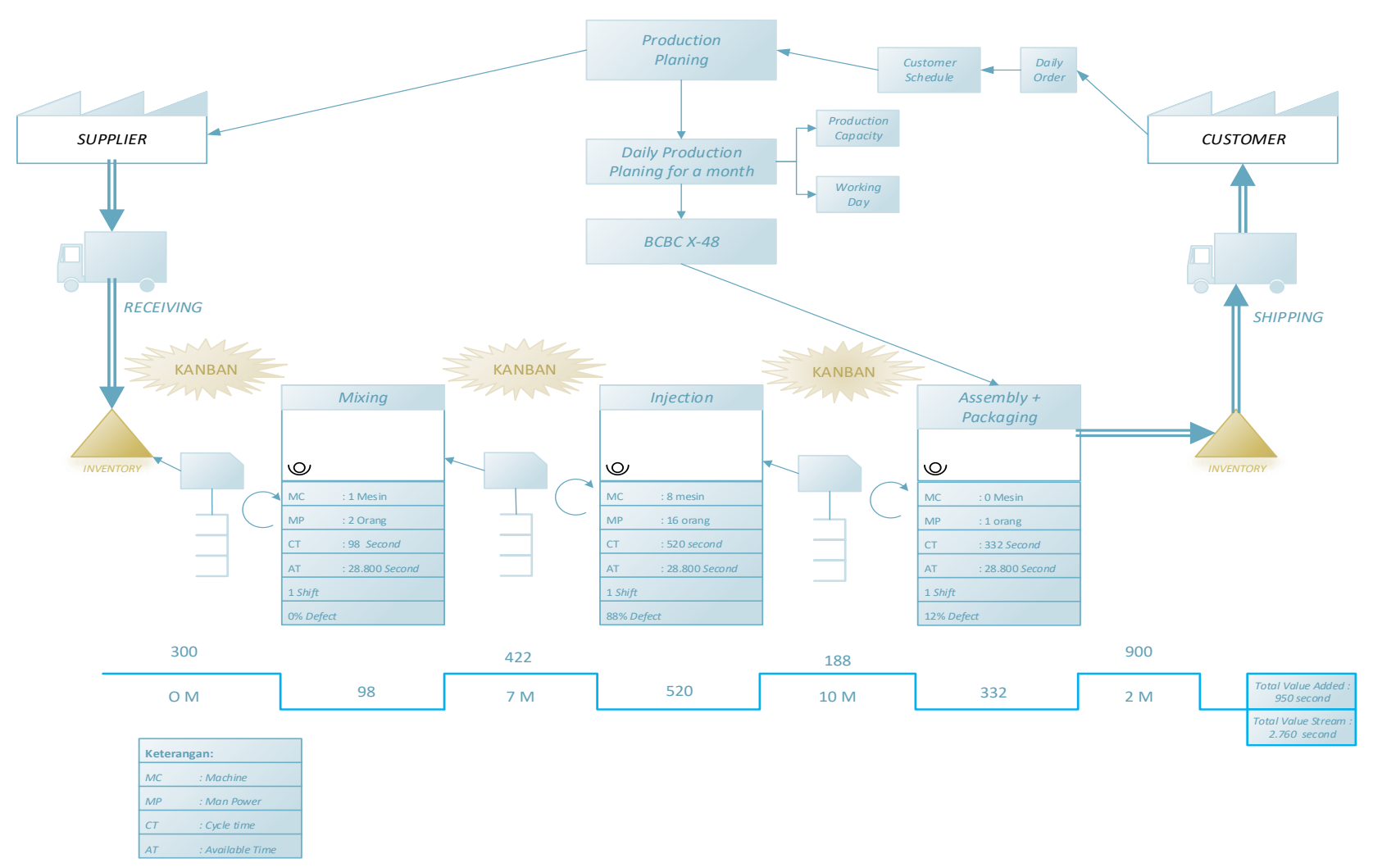

Fig. 8. Future Value Stream Mapping

\section{Conclusions}

The research discusses the implementation of Lean Six Sigma and TRIZ methods to reduce the industrial wastes in wood manufacture. The DMAIC methodology is used in order to determine the stages of the solutions. The types of dominant waste found are waiting, over-production, defect, and inventory from the analysis. The TRIZ method 
provides solutions for improvement by reforming the working stations. The strategy is proven to be effective, as shown by the significant decrease in NVA. The research suggests the future research calculate all aspects of waste in the wood manufacturing industry. Furthermore, the correlation between aspects of waste needs to be considered in the measurement of waste.

\section{Acknowledgments}

The authors would like to thank all who have helped in this research, especially the reviewers and editors who give feedback for improving the article.

\section{Reference}

[1] A. Cherrafi, S. Elfezazi, K. Govindan, J. A. Garza-Reyes, K. Benhida, and A. Mokhlis, "A framework for the integration of Green and Lean Six Sigma for superior sustainability performance," International Journal of Production $\begin{array}{lllll}\text { Research, } & \text { vol. } & 55, & \text { pp. } & 4481-4515,\end{array}$ https://doi.org/10.1080/00207543.2016.1266406.

[2] D. M. Utama, S. K. Dewi, and V. I. Mawarti, "Identifikasi waste pada proses produksi key set clarinet dengan pendekatan lean manufacturing," Jurnal Ilmiah Teknik Industri, vol. 15, pp. 36-46, 2016. https://doi.org/10.23917/jiti.v15i1.1572.

[3] A. M. Deif, "A system model for green manufacturing," Journal of Cleaner $\begin{array}{lllll}\text { Production, } & \text { vol. } & \text { 19, } & \text { pp. } & 1553-1559,\end{array}$ https://doi.org/10.1016/j.jclepro.2011.05.022.

[4] H. S. Sodhi, B. J. Singh, and D. Singh, "A conceptual examination of Lean, Six Sigma and Lean Six Sigma models for managing waste in manufacturing SMEs," World Journal of Science, Technology and Sustainable Development, vol. 17, pp. 2032, 2020. https://doi.org/10.1108/WJSTSD-10-2019-0073.

[5] H. B. Ismail and Z. B. M. Yusof, "Understanding Defects During the Construction Process," Advanced Science Letters, vol. 24, pp. 4227-4231, 2018.

[6] A. Karim and M. Islam, "Manufacturing practices and performance," International Journal of Quality \& Reliability Management, vol. 28, pp. 43-61, 2011. https://doi.org/10.1108/02656711111097544.

[7] J. Maleyeff and E. D. Arnheiter, "The integration of lean management and Six Sigma," The TQM Magazine, vol. 17, pp. 5-18, 2005. https://doi.org/10.1108/09544780510573020.

[8] E. Amrina and A. A. A. Lubis, "Minimizing waste using lean manufacturing: A case in cement production," in 2017 4th International Conference on Industrial Engineering and Applications (ICIEA), 2017, pp. 71-75. https://doi.org/10.1109/IEA.2017.7939181.

[9] M. De la Vega-Rodríguez, Y. A. Baez-Lopez, D.-L. Flores, D. A. Tlapa, and A. Alvarado-Iniesta, "Lean Manufacturing: A Strategy for Waste Reduction," in New Perspectives on Applied Industrial Tools and Techniques, J. L. García-Alcaraz, G. Alor-Hernández, A. A. Maldonado-Macías, and C. Sánchez-Ramírez, Eds., ed Cham: Springer International Publishing, 2018, pp. 153-174. https://doi.org/10.1007/978-3-319-56871-3_8. 
[10] N. A. A. Rahman, S. M. Sharif, and M. M. Esa, "Lean manufacturing case study with Kanban system implementation," Procedia Economics and Finance, vol. 7, pp. 174-180, 2013. https://doi.org/10.1016/S2212-5671(13)00232-3.

[11] D. Romero, P. Gaiardelli, D. Powell, T. Wuest, and M. Thürer, "Digital Lean CyberPhysical Production Systems: The Emergence of Digital Lean Manufacturing and the Significance of Digital Waste," in Advances in Production Management Systems. Production Management for Data-Driven, Intelligent, Collaborative, and Sustainable Manufacturing, Cham, 2018, pp. 11-20. https://oi.org/10.1007/978-3319-99704-9_2.

[12] C. Bai, A. Satir, and J. Sarkis, "Investing in lean manufacturing practices: an environmental and operational perspective," International Journal of Production $\begin{array}{lllll}\text { Research, } & \text { vol. } & 57, & \text { pp. } & 1037-1051,\end{array}$ https://doi.org/10.1080/00207543.2018.1498986.

[13] M. Ade and V. Deshpande, "Lean manufacturing and productivity improvement in coal mining industry," International Journal of Engineering Research and Development, vol. 2, pp. 35-43, 2012.

[14] R. Trehan, A. Gupta, and M. Handa, "Implementation of Lean Six Sigma framework in a large scale industry: a case study," International Journal of Six Sigma and Competitive Advantage, vol. 11, pp. 23-41, 2019. https://doi.org/10.1504/IJSSCA.2019.098710.

[15] J. Antony, D. A. Desai, and M. B. Patel, "An assessment of the critical success factors for Six Sigma implementation in Indian industries," International Journal of Productivity and Performance Management, vol. 61, pp. 426-444, 2012. https://doi.org/10.1108/17410401211212670.

[16] A. Sulaksmi, "Penerapan Lean Sigma untuk Menggurangi Waste pada Produksi Benih Jagung," Jurnal Teknik Industri, vol. 8, pp. 88-98, 2008. https://doi.org/10.22219/JTIUMM.Vol8.No1.88-98.

[17] J. Ochieng, J. Douglas, and A. Douglas, "Lean Six Sigma implementation in East Africa: findings from a pilot study," The TQM Journal, vol. 27, pp. 772-780, 2015. https://doi.org/10.1108/TQM-05-2015-0066.

[18] A. Sohal and R. J. Hilton, "A conceptual model for the successful deployment of Lean Six Sigma," International Journal of Quality \& Reliability Management, vol. 29, pp. 54-70, 2012. https://doi.org/10.1108/02656711211190873.

[19] A. J. Thomas, M. Francis, R. Fisher, and P. Byard, "Implementing Lean Six Sigma to overcome the production challenges in an aerospace company," Production Planning \& Control, vol. 27, pp. 591-603, 2016. https://doi.org/10.1080/09537287.2016.1165300.

[20] D. Micu, "Six Sigma: tools and methodology for the clothing industry," in Proceedings of The 6th International Management Conference Approaches In Organizational Management, Bucharest, 2012, pp. 505-510.

[21] P. Manfredsson, O.-P. Hilmola, P. Hilletofth, and R. Andersson, "Lean Six Sigma strategy in telecom manufacturing," Industrial Management \& Data Systems, vol. 114, pp. 904-921, 2014. https://doi.org/10.1108/IMDS-02-2014-0069.

[22] I. Belekoukias, J. A. Garza-Reyes, and V. Kumar, "The impact of lean methods and tools on the operational performance of manufacturing organisations," International Journal of production research, vol. 52, pp. 5346-5366, 2014. https://doi.org/10.1080/00207543.2014.903348.

Please cite this article as: Purnomo, D. H., \& Lukman, M. (2020). Reduce Waste using Integration of Lean Six Sigma and TRIZ Method: A Case Study in Wood Industry. Jurnal Teknik Industri, 21(2), 139-152. https://doi.org/10.22219/JTIUMM.Vol21.No2.139-152 
[23] A. Chiarini, "Risk management and cost reduction of cancer drugs using Lean Six Sigma tools," Leadership in Health Services, vol. 25, pp. 318-330, 2012. https://doi.org/10.1108/17511871211268982.

[24] A. Chiarini and E. Bracci, "Implementing Lean Six Sigma in healthcare: issues from Italy," Public Money \& Management, vol. 33, pp. 361-368, 2013. https://doi.org/10.1080/09540962.2013.817126.

[25] A. Soti, R. Shankar, and O. P. Kaushal, "Six Sigma with innovation tool kit of TRIZ," International Journal of Business Innovation and Research, vol. 6, pp. 220237, 2012. https://doi.org/10.1504/IJBIR.2012.045638.

[26] L. B. M. Costa, M. Godinho Filho, L. D. Fredendall, and G. M. Devós Ganga, "Lean six sigma in the food industry: Construct development and measurement validation," International Journal of Production Economics, vol. 231, p. 107843, 2021. https://doi.org/10.1016/j.ijpe.2020.107843.

[27] F. Nabhani, S. Bala, G. Evans, and A. Shokri, "Review of implementing lean six sigma to reduce environmental wastes of internal supply chains in food industry," in 15th international conference on manufacturing research, ICMR 2017, 2017, pp. 327-332.

[28] L. Chechurin, "TRIZ in science. Reviewing indexed publications," Procedia CIRP, vol. 39, pp. 156-165, 2016. https://doi.org/10.1016/j.procir.2016.01.182.

[29] D. Nallusamy, R. Nivedha, E. Subash, V. Venkadesh, S. Vignesh, and P. kumar, "Minimization of Rejection Rate using Lean Six Sigma Tool in Medium Scale Manufacturing Industry," International Journal of Mechanical Engineering and Technology, vol. 9, pp. 1184-1194, 2018.

[30] D. Black, "Partial justification of the Borda count," Public Choice, vol. 28, pp. 1-15, 1976. https://doi.org/10.1007/BF01718454.

[31] A. R. Singh, V. Swarnakar, and A. K. Tiwari, "Evaluating the effect of critical failure factors associated with sustainable Lean Six Sigma framework implementation in healthcare organization," International Journal of Quality \& Reliability Management, vol. ahead-of-print, 2020. https://doi.org/10.1108/IJQRM07-2020-0243.

[32] A. Coskun, W. P. Oosterhuis, M. Serteser, and I. Unsal, "Sigma metric or defects per million opportunities (DPMO): the performance of clinical laboratories should be evaluated by the Sigma metrics at decimal level with DPMOs," Clinical Chemistry and Laboratory Medicine (CCLM), vol. 54, pp. e217-e219, 2016. https://doi.org/10.1515/cclm-2015-1219.

[33] P. Hines and N. Rich, "The seven value stream mapping tools," International Journal of Operations \& Production Management, vol. 17, pp. 46-64, 1997. https://doi.org/10.1108/01443579710157989.

[34] S. Kabir, "An overview of fault tree analysis and its application in model based dependability analysis," Expert Systems with Applications, vol. 77, pp. 114-135, 2017. https://doi.org/10.1016/j.eswa.2017.01.058.

[35] D. Cavallucci, TRIZ-The Theory of Inventive Problem Solving: Current Research and Trends in French Academic Institutions vol. 1: Springer, 2017. https://doi.org/10.1007/978-3-319-56593-4.

[36] P. Tsarouhas, "Statistical analysis of failure data for estimating reliability, availability and maintainability of an automated croissant production line," Journal of Quality in Maintenance Engineering, vol. 25, pp. 452-475, 2019. https://doi.org/10.1108/JQME-04-2018-0029. 
[37] B. S. Kothavale, S. G. Joshi, L. Y. Waghmode, and R. B. Patil, "Reliability analysis of CNC turning center based on the assessment of trends in maintenance data," International Journal of Quality \& Reliability Management, vol. 34, pp. 1616-1638, 2017. https://doi.org/10.1108/IJQRM-08-2016-0126.

[38] I. Q. Alsaffar and H. S. Ketan, "Integrating of Lean Six Sigma methodology and ergonomics principles for improvement in an assembly industrial workstation," $\begin{array}{llllll}\text { Journal of Engineering, vol. 25, pp. } 2019 . & \text { 12-29, }\end{array}$ https://doi.org/10.31026/j.eng.2019.09.2.

[39] J.-M. Barragan-Ferrer, S. Negny, J. Damasius, D. Barragan-Ferrer, and D. Cizeikiene, "TRIZ evolution trends as an approach for predicting the future development of the technological systems in the food industry," in Managing Innovation in Highly Restrictive Environments, ed: Springer, 2019, pp. 247-277. https://doi.org/10.1007/978-3-319-93716-8_12.

[40] L. Gaikwad, V. Sunnapwar, and S. N. Teli, "Adaption of TRIZ method for problem solving: a case study," International Journal of Six Sigma and Competitive $\begin{array}{lllll}\text { Advantage, } & \text { vol. } & 10, & \text { pp. }\end{array}$ https://doi.org/10.1504/IJSSCA.2016.080804.

[41] F. Z. Ben Moussa, I. Rasovska, S. Dubois, R. De Guio, and R. Benmoussa, "Reviewing the use of the theory of inventive problem solving (TRIZ) in green supply chain problems," Journal of Cleaner Production, vol. 142, pp. 2677-2692, 2017. https://doi.org/10.1016/j.jclepro.2016.11.008.

[42] S. L. Furterer, Lean Six Sigma in service: applications and case studies: CRC press, 2016.

[43] B. J. Galli and M. A. Kaviani, "The impacts of risk on deploying and sustaining Lean Six Sigma initiatives," International Journal of Risk and Contingency $\begin{array}{llllll}\text { Management } & \text { (IJRCM), } & \text { vol. } & \text { 7, } & \text { pp. } & 46-70,\end{array}$ http://doi.org/10.4018/IJRCM.2018010104. 